\title{
Islamic Perspective
}

\section{Islamic Medicine and Evolutionary Medicine: A Comparative Analysis}

DOI: http://dx.doi.org/10.5915/44-1-8780

\author{
Arthur Saniotis, PhD \\ School of Medical Sciences. The University of Adelaide \\ Adelaide, Australia \\ Centre for Evolutionary Medicine, University of Zürich \\ Zürich, Switzerland
}

\begin{abstract}
The advent of evolutionary medicine in the last two decades has provided new insights into the causes of human disease and possible preventative strategies. One of the strengths of evolutionary medicine is that it follows a multi-disciplinary approach. Such an approach is vital to future biomedicine as it enables for the infiltration of new ideas. Although evolutionary medicine uses Darwinian evolution as a heuristic for understanding human beings' susceptibility to disease, this is not necessarily in conflict with Islamic medicine. It should be noted that current evolutionary theory was first expounded by various Muslim scientists such as al-Jāhịiz, al-Ṭūsī, Ibn Khaldūn and Ibn Maskawayh centuries before Darwin and Wallace. In this way, evolution should not be viewed as being totally antithetical to Islam. This article provides a comparative overview of Islamic medicine and Evolutionary medicine as well as drawing points of comparison between the two approaches which enables their possible future integration.
\end{abstract}

Key words: tawhīd, fițra, microcosm-macrocosm, mismatch, integration, Islamic Medicine, Evolutionary Medicine

\section{Introduction}

Islamic medicine and evolutionary medicine provide unique insights into human health and disease. The growth of evolutionary medicine in the last twenty years has been mainly due to its multi-disciplinary approach. Its North American and European scientific proponents argue that there is a need for medicine to utilize evolutionary principles in understanding human disease. Of course, evolutionary principles to understanding disease are not new but were developed in Islamic science over one thousand years ago. What is new perhaps are the different sciences, such as molecular biology, that are available for testing evolutionary hypotheses. I argue that the principles of Islamic medicine and evolutionary medicine are not irreconcilable but can assist in each other's theoretical scope. This

Correspondence should be directed to

Arthur Saniotis

arthur.saniotis@adelaide.edu.au paper provides an overview of Islamic medicine and evolutionary medicine and emphasizes points of comparison which can form the basis for a possible future integration of both approaches.

\section{Islamic Medicine: An Overview}

Increasing scholarly interest in Islamic medicine in the western world has enabled western audiences to access traditional Islamic thought. ${ }^{1-6}$ Many of these authors discuss historical, philosophical and sociological elements that have influenced Islamic medicine. Firstly, Islamic medicine should be differentiated from Prophetic Medicine (al-Tibb al-Nabawì). Prophetic Medicine was developed during the time of the Prophet Muhammad and includes herbal lore, hygiene and dietary practices and exercise regimes. Islamic medicine is the body of medical knowledge and practice which began in the early Islamic period and which is being currently practiced by Muslim physicians in Muslim and non-Muslim countries. In 1983 Dr. Elkadi at an IMANA meeting defined Islamic 
medicine as "The most up-to-date medical science and technology combined and conforming with the Divine teachings of Islam." Although based on an Islamic perspective, Islamic medicine also incorporates modern medical techniques in the service of healing. While Islamic medicine heralds a litany of therapeutic techniques, the Muslim physician and patient must always acknowledge that the "ultimate cure is from Allah.".

The rudiments of Islamic medicine began with the advent and spread of Islam (circa $7^{\text {th }}$ century C.E.). The Qur'an and the Prophetic traditions (hadith) discuss the importance of personal hygiene and public health. As stated earlier, The Prophet Muhammad prescribed correct dietary habits, such as commensality, prayers and exercise in order to promote physical and spiritual well-being. The Qur'an also indicates how it can benefit humankind.

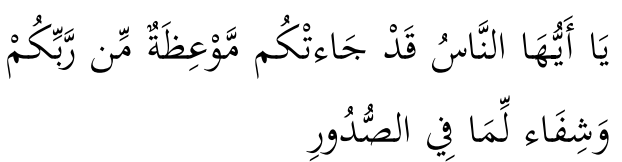

O mankind! There has come to you a good advice from your Lord (i.e. the Qur'an), and a healing for that which is in your hearts.

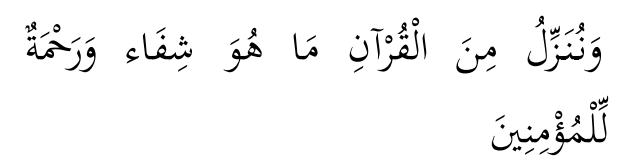

And We send down from the Qur'an that which is a healing and a mercy to those who believe ... ${ }^{10}$

Muslims developed a medical compendium based on the Qur'an and hadith called Prophetic medicine that is widely used in the Muslim world. Early Muslim focus on medicine was fostered by the Qur'an and the hadith, as characterized in the following saying the Prophet Muhammad:

$$
\text { ما أنزل الله داء إلا أنزل له شفاء }
$$

Allah has not sent any disease without sending a cure for it. ${ }^{11}$

With the expansion of Islam in North Africa, Western and Southern Asia and the Iberian Peninsula, Muslims came into contact with various civilizations with their own bodies of medical knowledge. Guided by Qur'anic and Prophetic injunctions to seek and cultivate knowledge, Muslims from the $7^{\text {th }}$ century onwards assiduously accessed the knowledge of the ancient world. This pursuit of knowledge was exemplified in the "translation revolution" during the Abassid dynasty (750-1258 C.E). It was during this period that Islamic civilization flourished due to its concerted investment in the sciences and the arts. Various Muslim and nonMuslim thinkers translated scientific works in Arabic from Greek, Persian, Syriac, Aramaic and Indian languages. ${ }^{12,13}$ The basis of Islamic medicine was developed by Greek traditions, particularly Hippocratic and Galenic theories. Muslims resynthesized and innovated these medical traditions into a highly refined medical model that was logical, experimental and evidence based..$^{14}$ Although the Muslim world produced many highly erudite Muslim physicians, five individuals are outstanding for their developments to Islamic medicine. These were alRāzī (865-925), al-Zahrāwī (936-1013), ibn Sīna (980-1037), ibn Rushd (1126-1198) and ibn Nafīs (1213-1288). While space does not allow me to detail their many medical contributions, their insights have informed modern biomedicine.

A study of Islamic understandings of health and illness must begin with an analysis of the concept of tawhid (Divine Unity) which underpins Islamic medicine. Tawhì expresses the absolute oneness of Allah as contained in the first half of the shahāda (testament of faith) (lā 'ilāha 'illā Allāh: there is no god but God). Implied in the concept of tawhid is that all existence is inter-connected, inter-related and dependent on the Divine. Creation is a Divine act of mercy (rahma) that is expressed by the natural order (al-fitra). In scientific terminology, al-fitra is expressed by nature's kaleidoscopic meta-patterns which possess symmetry and beauty. According to Sharia'ti, ${ }^{15}$ as the organizational principle of existence, tawhid extends to scientific and social domains whereby nature, humanity and knowledge are understood as unities. Nasr elegantly states this principle:

The spirit of Islam emphasizes, by contrast, the unity of Nature, that unity that is the aim of the cosmological sciences, and that is adumbrated and prefigured in the 
continuous interlacing of arabesques uniting the profusion of plant life with the geometric crystals of the verses of the Quran. ${ }^{16}$

Islamic cosmology considers creation as a book of signs ( $\bar{a} y \bar{a} t)$ waiting to be revealed to those individuals with spiritual understanding. Indeed, the Qur'an makes constant reference that nature reflects the Divine nature and that it is incumbent on all Muslims to seek and understand nature's signs. The Quranic ruling that highlights the symbolic aspect of nature was a major reason for fostering Islamic scientific inquiry. Both the cosmos and nature manifest Vestigio Dei. ${ }^{17}$

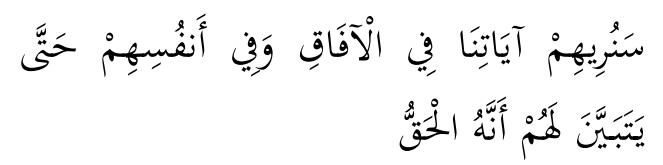

We shall show them our signs upon the horizons and within their souls until it becomes manifest to them that it is the truth. ${ }^{18}$

In traditional Islamic medicine the humankind (al-insān) is considered to be a microcosm ('ālam saghìr). The human body was essentially a miniature of the cosmos (al-'âlam), wherein its morphology and organization corresponded with those elements which "make up the wholeness of the universe." ${ }^{19}$ This notion of the inter-relatedness between the microcosm and the macrocosm is an expression of tawhid. Thus, Islamic medicine may be referred to as an ecological medical approach since it views the body in terms of an "organic totality and in its fundamental integration with the person." 20

\section{Evolutionary Medicine: An Overview}

The past two decades has seen the growth of evolutionary medicine, formerly known as Darwinian medicine. Courses in evolutionary medicine are now offered to medical students in over thirty North American and European universities. According to Randolph Nesse, a founder of evolutionary medicine, the inclusion of evolutionary medicine in university curricula has been a long time coming. One reason for this oversight has been the inability of medical practitioners to realize the importance of evolutionary principles in human disease. Recent advances in molecular biology such as the Human Genome Project have broadened medical understanding of the human body and its genetic vulnerabilities. ${ }^{21}$ A second reason for this lapse has been medical practitioners tendency to focus on proximal causes of disease. ${ }^{22}$ Evolutionary medicine combines the theoretical approaches of medical science, ecology, anthropology, biology, and psychology. The driving force behind this amalgamation is to provide insight into life-style and genetic-induced diseases. ${ }^{16}$ Since the $19^{\text {th }}$ century C.E., medical practitioners have increasingly learned about the relationship between environment and disease and how lifestyle and hygiene play a significant role. ${ }^{16}$

In their seminal book Why do We Get Sick: The New Science of Darwinian Medicine, George C. Williams and Randolph Nesse discuss various ways in which evolutionary theory can be applied to understanding human diseases. ${ }^{23}$ The main thesis of their book is that the human body has evolved over millions of years via a system of constraints and tradeoffs, informed by natural selection. For example, evolutionary theory argues that the narrowness of the human pelvis was shaped by natural selection in order to stabilize bipedalism. However, this evolutionary trade-off resulted in females having assisted and painful childbirth and altricial offspring. ${ }^{24}$ During human history fetal deaths during childbirth have been high (20\%-25\%). ${ }^{25}$ In addition, Keeler notes that maternal mortality among the Kuna Indians of Panama was approximately $30 \%$ up to the late twentieth century. ${ }^{26}$ Another possible evolutionary trade-off is sickle-cell anemia, which is found in individuals with two copies of the sickle-cell gene. In individuals who possess one copy each of sickled and unsickled cells, this confers some protection against malaria. While individuals with sickle-cell anemia may produce offspring with the homozygous form of the gene, this may be the cost of increased malarial resistance. ${ }^{27}$ Skin pigmentation in humans may also be viewed as an evolutionary trade-off. Modern research suggests that up until 100,000 years ago all Homo sapiens had dark skin pigmentation. As ancestral humans settled in northern regions, they were exposed to less sunlight, which may have prevented the reduction of gene variants for "lighter skin." Furthermore, lighter skin is better able to generate Vitamin D which may have given ancestral humans health benefits in an 
environment of reduced sunlight. ${ }^{28}$ In other words, the northern climate fostered a selective pressure for lighter skin.

A central idea of evolutionary medicine is based on the mismatch between biological and cultural evolution. While biological evolution is based on natural selection and mutations in the gene pool, cultural evolution is incrementally faster and is posited on novelty of the human mind. ${ }^{29}$ Moreover, natural selection does not "always match an organism's environment, especially where the environment transforms rapidly." ${ }_{30}$ As Nesse succinctly puts it, cultural factors "change faster than our bodies can evolve." ${ }_{31}$ When environmental conditions permanently change, evolutionary discordance arises between a species's genome and its environment, and stabilizing selection is replaced by directional selection, moving the average population genome to a new set point. $^{32-4}$

A key area in which the concept of mismatch has been used to explain various human vulnerabilities is in relation to human diet and changed eating patterns. The mismatch concept may assist us in understanding modern "diseases of civilization" (hypertension, obesity, type 2 diabetes, cancer, cardio-vascular disease). Trevathan explains that an evolutionary medical approach attempts to understand how human nutritional needs evolved under environmental conditions different from modern "diets and lifestyles, resulting in a "discordance" or "mismatch" between biology and lifestyle." ${ }_{35}$ Stearns et al argue that since cultural change is much faster than biological evolution, disease follows. ${ }^{36}$ According to the mismatch theory, ancestral humans had low caloric diets consisting of lean meat, fish and plants which were rich in micro-nutrients, complex carbohydrates and fiber. ${ }^{37-40}$ Ancestral humans were also physically active, walking approximately 20 kilometers per day when foraging for food. During the last ten thousand years, human diet has been dramatically modified. The agricultural revolution, which began approximately ten thousand years ago in the early Neolithic period, saw the introduction of seasonal agriculture such as cereals and animal domestication. The agricultural revolution began the trend towards diets which had more carbohydrate than protein. In addition, many human beings have sedentary lifestyles with little physical exertion. Sedentary lifestyles found in modern humans are "much lower than what the human genome was evolved for." ${ }_{41-4}$

However, since the agricultural revolution, there have been micro-evolutionary changes to specific human groups. For example, consumption of dairy foods in northern European groups began between 6100 to 5500 before present (BP). ${ }^{26}$ During this time, many northern Europeans have evolved low incidence of lactose intolerance (as low as 10\% in some European countries). ${ }^{45}$ In other words, many Northern European and East Africans peoples which use dairy foods are not hypolactasic. In contrast, non-dairy producing societies (i.e. East Asian regions, West Africa) have high incidence of lactose intolerance. Currently, approximately $70 \%$ of human beings worldwide are lactose intolerant during adulthood. ${ }^{46}$

\section{Islamic Medicine and Evolutionary Medicine: Points of Comparison}

Islamic medicine and evolutionary medicine share several points of comparison which will be explained further. Firstly, both medical approaches are analytical and emphasize inquiry and examination. The investigative nature of both medical approaches has developed peculiar insights into the human body. For instance, Muslim physicians possessed considerable knowledge on the etiology and treatment of metabolic disease. Islamic medicine was an evidence based approach as exemplified by alRāzì and other Muslim physicians. Islamic medicine heralded a disciplinary model which included quarantine, hospitals and systematic clinical training. ${ }^{47}$

A point of comparison is that both medical approaches acknowledge the fitra of the human body. While Islamic medicine recognizes the beauty and symmetry of the body as a microcosm, evolutionary medicine attributes the body with various considerable adaptations such as the immune system, and a specialized brain which endows humans with reflexive consciousness. Similarly, both medical approaches do not view the body as a machine as it is still popularized in biomedicine. For evolutionary medicine, the body is a complex evolutionary organism that does not behave anything like a machine. ${ }^{48}$ Accordingly, Islamic 
medicine considers the body's exquisite complexity as reflecting Allah's beauty.

Thirdly, both medical approaches promote health and well-being through correct diet and lifestyle. As stated earlier, the Qur'an and the hadith encourage Muslims to live in moderation and to develop spiritual, physical and psychological well-being. The Qur'an and hadith mention the use of olive oil, dates, black seeds, honey and vinegar as medicinal treatments. Moreover, the Prophet Muhammad extolled various foods for health, as well as, the benefits of exercise (i.e. horse riding, archery, swimming). The Prophet Muhammad also was a proponent of dental hygiene and recommended the use of the miswāk (toothbrush), particularly one made from a twig from Salvadora persica tree, to clean the teeth. ${ }^{49}$

Islamic medicine has a considerable repertoire of chemo-protective drugs and foods which stimulate the immune system and have anti-bacterial, anti-viral, antioxidant, antiinflammatory, and anti-cancer properties. ${ }^{50-3}$ The use of natural foods, herbs and spices such as black seed, olive products, melon, pomegranate, tumeric, bread wheat, garlic, figs ginger and onions are widely used by Muslims. According to Cragg et $\mathrm{al}^{49}$ and Zaid et $\mathrm{ll}^{54}$ these foods have anticancer properties.

Some advocates of evolutionary medicine such as Eaton, ${ }^{31}$ Abuissa et $\mathrm{al}^{36}$ and Cordain ${ }^{55}$ have written extensively on the problems with modern diets as contributing to chronic diseases via the overuse of refined carbohydrates and sugars, sodium and trans-fats in combination with sedentary lifestyles. These authors and others promote the Paleolithic diet, which closely resembles ancestral diet for optimal health. ${ }^{31,36,51,56-9}$ Their conclusion is that a decrease in dairy foods, cereal based foods and legumes and an increase in lean meat, fish, nuts, leafy green vegetables and fruits are required. ${ }^{60-4}$

Fourthly, Islamic medicine and evolutionary medicine recognize that life is a unity and that all living organisms are inter-related. The Qur'an states in many verses how nature and the cosmos were formed through gradual stages.

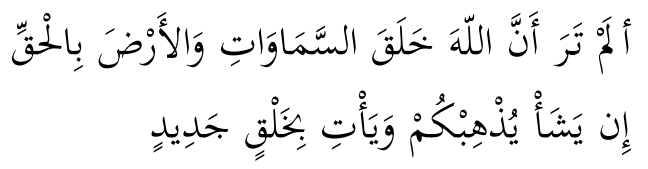

Have you not seen that Allah has created the heavens and the earth with the right proportions? If He wills, He can remove you and bring (in your place) a new creation. ${ }^{65}$

$$
\text { وَالسَّمَاء بَنَيْنَاهَا بِأَيْدِدٍ وَإِنَّا لَمُوسِعُونَ }
$$

We have built the heaven with power, and We are expanding (it). ${ }^{6}$

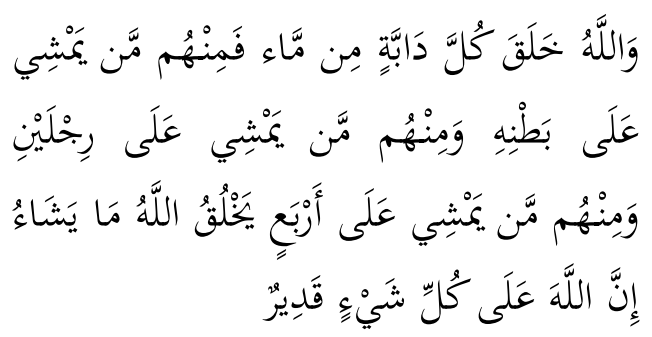

Allah has created every animal out of water. Of them (is a category which) walks upon its belly, (another which) walks upon two legs, and (a third which) walks upon four. Allah creates what He wills. Allah is Able to do everything (he wants). ${ }^{67}$

Early Muslim scientists such as al-Jāhiz (776869) and Nasīr al-Dīn al-Tūsī (1201-1274) espoused evolutionary concepts which closely resemble Darwinian evolutionary theory. For example, al-Jāhị believed in a Divinely designed environmental determinism and natural selection and how the environment shaped adaptive phenotypical traits. He also recognised that biological fitness of species was necessary to sustain the web of life. Al-Jāhiz understood that living organisms developed through a struggle to exist and had an "innate desire for conservation" and continuity, which was a form of natural selection. Moreover, the struggle for existence is Divinely guided. ${ }^{68-9}$ This struggle operated among members of a species and among different species.

Animals engage in a struggle for existence; for resources, to avoid being eaten and to breed. ... Environmental factors influence organisms to develop new characteristics to ensure survival, thus transforming into new species. Animals that survive to breed can pass 
on their successful characteristics to offspring. ${ }^{70}$

Al-Ṭūsi expressed the concept of hereditary viability as being central to evolution. Al-Ṭūsì notes that: "The organisms that can gain the new features faster are more variable. As a result, they gain advantages over other creatures." ${ }^{71} \mathrm{Al}-$ Ṭussi noticed that there is a correlation between an organism's morphology and adaptive environment. Al-Tūisi writes: "Look at the world of animals and birds. They have all that is necessary for defence, protection and daily life, including strengths, courage and appropriate tools [organs]." ${ }^{63}$ Al-Ṭūsī also criticized the entrenched Ptolemaic geocentric model, and over many years accurately calculated the positions of the planets which was found in his book Zij-i ilkhani. The construction of an astronomical observatory (with the permission of Hulegu Khan) in 1259 enabled al-Ṭūsi and his colleagues to precisely observe the movements of the planets and stars which led to an advanced understanding of the planets during this period. Moreover, al-Ṭusîs findings led to the development of the heliocentric model which is credited to the Polish priest Nicolaus Copernicus in 1543. However, much of the credit should go to al-Ṭūsī.

In The Muqaddimah, Ibn Khaldūn (1332-1406) offers a theory of evolution which resembles modern principles of evolutionary theory.

One should then take a look at the world of creation. It started out from the minerals and progressed, in an ingenious, gradual manner, to plants and animals... The animal world then widens, its species become numerous, and, in a gradual process of creation, it finally leads to man, who is able to think and reflect. At this point we come to the first stage of man. This is as far as our (physical) observation extends. ${ }^{72}$

Ibn Khaldūn also disputed the Talmudic notion of human descent which based a distinction on human descendents of Noah. According to the Talmudic tradition the "descendants of Ham are cursed by being black, and (it) depicts Ham as a sinful man and his progeny as degenerates." ${ }^{73}$ According to Ibn
Khaldūn, the dark skin pigmentation of Sudanese Africans was due to climatic heat, and that skin pigmentation lightened as people lived in more northern regions. ${ }^{74}$ His hypothesis was correct.

Similarly, evolutionary medicine utilizes natural selection ${ }^{75}$ and genetic variation for explaining human adaptive traits and susceptibilities to disease. ${ }^{76-7}$ There is a recognition that all life evolved from a single ancestor approximately 3.9-3.4 billion years ago which led to the rise of protozoan and multicellular life forms. Furthermore, all life is intrinsically related as having DNA to store genetic information and cellular structures.

There have been several versions of evolutionary theory over the past five thousand years. The Ionian Philosopher Anaximander (611-546 B.C.E.) postulated that the earth was in its early stages covered in water and that humankind had evolved from fish. Xenophanes of Colophon (died ca. 490 B.C.E.), a disciple of Anaximander, examined shell fossils and reaffirmed his teacher's position that the earth had been underwater during an earlier period.

The concept of water and creation is also central to Mesopotamian cosmogonies. For example, Sumerians believed that at the dawn of time there was a primordial sea (Nammu). It is Nammu who created heaven and earth, while another god called Enki (god of the underworld sea) created humankind from clay. According to Babylonian cosmogony, all the gods had emerged from the primordial waters.

Evolutionary concepts were also elaborated by the Greek philosopher Empedocles (492-432 B.C.E.). Empedocles purported his own version of the origin of the species which was not dependent on an external agency or design. His exposition on zoogony included flora and fauna (including humans). In short, Empedocles believed that creatures that had been malformed did not survive while those creatures which had homogenous limbs survived and founded extant species.

\section{Conclusion: Possible Future Integration of} Islamic Medicine and Evolutionary Medicine

While Islamic medicine and evolutionary medicine have derived from different historic and social contexts, their approaches can find future areas of integration. From an Islamic medical perspective, it can expand evolutionary medicine's notion of the human being as both a 
biological and spiritual entity. In other words, viewing humans in a more holistic manner will help to improve medical interventions. On this note, Dossey encourages the future use of nonlocal techniques such as intercessory prayer, distance healing and transpersonal imagery as part of medical therapeutic techniques. ${ }^{78}$ Such spiritual based techniques are also a feature of Islamic medicine. Additionally, the Islamic principle of tawhid can further provide adherents of evolutionary science into nature's integrative meta-patterns which form the cybernetic and informational processes of life. ${ }^{79}$ The noted thinker Gregory Bateson contends that religious systems may provide a way for understanding "the communicative interconnection among all living organisms." ${ }^{80}$ The concept of tawhid may also relate to "feedback awareness" in nature and how humans are inter-connected with other species. I would also argue that evolutionary medicine can draw upon concepts of Islamic medicine in order to make the former's hypotheses more rigorous. Evolutionary medicine is a recent development and is still in the process of refining its concepts. In contrast, Islamic medicine is over one thousand years old and has empirical and theoretical rigor.

\section{References}

1. Nagamia HF. New definitions of Islamic medicine: 'Neo-Islamic medicine.' J Islam Med Assoc. 1996;28:100-101. http://doi.org/ds64kg

2. Rahman F. Health and medicine in the Islamic tradition. New York: Crossroads Publishing; 1989. 3. Attewell G. Islamic medicines: perspectives on the Greek legacy in the history of Islamic medical traditions in West Asia. In: Selin H, ed. Medicine across cultures. Dordrecht: Kluwer Academic Publishers; 2002:325-50.

4. Muzaffar I. Science and Islam. Westport, Conn.: Greenwood Press; 2007.

5. Bouzenita AI. Formulating an Islamic model of science and bioethics. J Islam Med Assoc. 2009;41:114-21. http://doi.org/h2f

6. Yacoub AA. The figh of medicine. London: Ta Ha Publishers; 2001.

7. Elkadi A. Islamic medicine in North America. J Islam Med Assoc. 1984;16:8-10. http://doi.org/h2g

8. Fadel HE. What is Islamic medicine? How does it relate to contemporary medicine? J Islam Med Assoc. 2008;40:57. http://doi.org/h2d

9. The Glorious Qur'an, Chapter 10, Verse 57.
10. The Glorious Qur'an, Chapter 17, Verse 82. 11. Șahịh al-Bukhārī. Kitāb al-țibb. Bāb mā anzala Allāh dā' illā anzala lahu shifā'. Hadith no. 5354. muhaddith.org

12. Khan FA. Approaching modern technological challenges through the traditions of Ibn Sinna (980-1036). J Islam Med Assoc 2008; 40:15-22. http://dx.doi.org/10.5915/40-1-5280

13. Nagamia HF, Puyan N. Abū Zayd Hunayn ibn Ishāa al-'Ibādī: a physician translator par excellence. J Islam Med Assoc. 2008;40:9-14. http://dx.doi.org/10.5915/40-1-5279

14. Ebrahimnejad H. What is 'Islamic' in Islamic Medicine? An overview. Boston Studies in the Philosophy of Science. 2011;275:259-70. http://dx.doi.org/10.1007/978-90-481-9968-6_17

15. Shari'ati A. On the sociology of Islam. Oneonta, New York: Mizan Press; 1979.

16. Nasr SH. Science and civilization in Islam. New York: New American Library; 1968.

17. Nasr SH. Islamic art and spirituality. Suffolk: Golgonooza Press; 1987.

18. The Glorious Qur'an, Chapter 41, Verse 53.

19. El-Bizri N. The microcosm/macrocosm analogy: a tentative encounter between GraecoArabic philosophy and phenomenology. In: Tymieniecka A, ed. Islamic philosophy and occidental phenomenology on the perennial issue of microcosm and macrocosm. Dordrecht, The Netherlands; Springer; 2006: 3-23. http://dx.doi.org/10.1007/978-1-4020-4115-0_1

20. Campbell CS. Religion and the body in medical research. Kennedy Inst Ethics J. 1998; 8:275-305. http://doi.org/fg9gnv

21. Nesse RM, Bergstrom CT, Ellison PT, Flier JS, Gluckman P, Govindaraju DR, Niethammer D, Omenn GS, et al. Evolution in health and medicine Sackler colloquium: Making evolutionary biology a basic science for medicine. Proc Natl Acad Sci U S A. 2010;107 Suppl 1:1800-7. http://doi.org/d3crt7

22. Hood E, Jenkins KP. Evolutionary medicine: a powerful tool for improving human health. Evolution: Education and Outreach. 2008;1:11420. http://dx.doi.org/10.1007/s12052-008-0036-9 23. Williams G, Nesse RM. Why we get sick: the new science of Darwinian medicine. New York: Vintage Books; 1994.

24. Weiner S, Monge J, Mann A. Bipedalism and parturition: an evolutionary imperative for caesarean delivery? Clin Perinatol. 2008; 35:46978. http://dx.doi.org/10.1016/j.clp.2008.06.003 
25. Abitbol MM. Birth and human evolution: anatomical and obstetrical mechanics in primates. Westport (CT): Bergin \& Garvey; 1996.

26. Keeler CE. Land of the moon-children: the primitive San Blas culture in flux. Athens (GA): University of Georgia Press; 1956.

27. Shanahan T. Darwinian medicine. Presentation to the LMU Department of Biology Seminar Series. http://bit.ly/LlmHWT [Updated 1999-Oct-19; Accessed 2012-May-16]

28. Jablonski NG, Chaplin G. The evolution of human skin coloration. J Human Evol. 2000;39:57-106. http://doi.org/dh4pjh

29. Saniotis A. Evolutionary medicine: a biocosmological approach for informing future biomedicine. Biocosmology - neo-Aristotelism. 2010; 1:99-111. http://bit.ly/Jq31j6

30. Lende DH, Smith EO. Evolution meets biopsychosociality: an analysis of addictive behavior. Addiction. 2002;97:447-58. http://doi.org/bk363b

31. Nesse, R. What Darwinian medicine offers psychiatry. In: Trevathan W, Smith EO, McKenna JJ, eds. Evolutionary medicine. New York and Oxford: Oxford University Press; 1999: 351-377.

32. Trevathan WR, McKenna JJ Smith EO. eds. Evolutionary medicine. $2^{\text {nd }}$ edition. New York: Oxford University Press; 2007.

33. Stearns SC, Koella JK, eds. Evolution in health and disease. $2^{\text {nd }}$ edition. Oxford: Oxford University; 2007.

34. Cordain L, Eaton SB, Sebastian A, et al. Origins and evolution of the Western diet: health implications for the 21st century. Am J Clin Nutr. 2005;81:341-54. PubMed PMID: 15699220

35. Trevathan WR. Evolutionary medicine. Annual Review of Anthropology. 2007; 36:139154. http://doi.org/c4xjv9

36. Stearns SC, Nesse RM, Govindaraju DR, Ellison PT. Evolution in health and medicine Sackler colloquium: Evolutionary perspectives on health and medicine. Proc Natl Acad Sci U S A. 2010;107:1691-5. http://doi.org/bpc263

37. Eaton SB, Eaton SB 3rd, Konner MJ. Paleolithic nutrition revisited: a twelve-year retrospective on its nature and implications. European Journal of Clinical Nutrition. 1997;51:207-16. http://doi.org/bnv62g

38. Eaton SB, Cordain L, Eaton SB. An evolutionary foundation for health promotion. World Rev Nutr Diet. 2001;90:5-12. http://dx.doi.org/10.1159/000059815
39. Eaton SB. Preagricultural diets and evolutionary health promotion. In: Ungar P, ed. Evolution of the human diet: the known, the unknown, and the unknowable. Oxford, USA: Oxford University Press; 2007: 572-91.

40. Ungar PS, Grine FE, Teaford MF. Diet in early Homo: a review of the evidence and a new model of adaptive versatility. Annual Review of Anthropology. 2006;35:209-28.

http://doi.org/dqvb4j

41. Marlowe FW. Hunter-gatherers and human evolution. Evolutionary Anthropology. 2005; 14:54-67. http://dx.doi.org/10.1002/evan.20046

42. Saniotis A. Evolutionary medicine and bioethics: an Asian perspective. Calicut Medical Journal. 2010;8(4):e4.

43. Cordain L, Eaton SB, Sebastian A, et al. Origins and evolution of the Western diet: health implications for the $21^{\text {st }}$ century. Am J Clin Nutr. 2005;81:341-54. PubMed PMID: 15699220

44. Abuissa H, O'Keefe JH Jr, Cordain L. Realigning our 21st century diet and lifestyle with our hunter-gatherer genetic identity. Directions in Psychiatry. 2005;25:SR1-SR10.

45. Matthews SB, Waud JP, Roberts AG, Campbell AK. Systemic lactose intolerance: a new perspective on an old problem. Postgrad Med J. 2005;81:167-73. http://doi.org/cvg4vq

46. Heyman MB, Committee on Nutrition. Lactose intolerance in infants, children, and adolescents. Pediatrics. 2006; 118:1279-86. http://dx.doi.org/10.1542/peds.2006-1721

47. Syed IB. Medicine and medical education in Islamic history. In: Athar $\mathrm{S}$, ed. Islamic perspectives in medicine. Indianapolis: American Trust Publishers; 1993: 45-56.

48. Nesse RM, Stearns SC. The great opportunity: evolutionary applications to medicine and public health. Evolutionary Applications. 2008;1:28-48. http://doi.org/dpbz9h

49. Rahman MT. Islamic guidelines for healthful living. J Islam Med Assoc. 2007;39:158-67.

http://dx.doi.org/10.5915/39-4-6320

50. Cragg GM, Newman DJ. Plants as a source of anti-cancer agents. J Ethnopharmacol. 2005;100:72-9. http://doi.org/dp5q58

51. Saad B, Azaizeh H, Said O. Arab herbal medicine. In: Watson RR, Preedy VR, editors. Botanical medicine in clinical practice. Wallingford, UK and Cambridge, Massachusetts: CABI; 2008: 31-9.

52. Al-Johar D, Shinwari N, Arif J, et al. Role of Nigella sativa and a number of its antioxidant 
constituents towards azoxymethane-induced genotoxic effects and colon cancer in rats. Phytopher Res. 2008;22:1311-23.

http://dx.doi.org/10.1002/ptr.2487

53. Cragg GM, Grothaus PG, Newman DJ. Impact of natural products on developing new anticancer agents. Chem Rev. 2009;109:3012-43. http://dx.doi.org/10.1021/cr900019j

54. Zaid H, Rayan A, Said O, Saad B. Cancer treatment by Greco-Arab and Islamic herbal medicine. The Open Nutraceuticals Journal. 2010;3:203-212. http://doi.org/btcvtc

55. Cordain L. Implications of Plio-Pleistocene hominin diets for modern humans. In: Ungar P, ed. Evolution of the human diet: the known, the unknown, and the unknowable. Oxford, USA: Oxford University Press; 2007:539-71.

56. Lindeberg S, Cordain L, Eaton SB. Biological and clinical potential of a Palaeolithic diet. Journal of Nutritional and Environmental Medicine. 2003;13:149-60. http://doi.org/dr8hhb 57. Gowlett JAJ. What actually was the Stone Age Diet? Journal of Nutritional and Environmental Medicine. 2003;13:143-7. http://doi.org/d4xxgx

58. Abrams HL Jr. The relevance of Paleolithic diet in determining contemporary nutritional needs. Journal of Applied Nutrition. 1979;31:4359.

59. Eaton SB, Konner M. Paleolithic nutrition -- a consideration of its nature and current implications. N Engl J Med. 1985;312:283-9. http://doi.org/fshbj3

60. Cordain L. Cereal grains: humanity's doubleedged sword. In: Simopoulos AP, editor. Evolutionary aspects of nutrition and health. Diet, exercise, genetics and chronic disease. World Review of Nutrition and Dietics. 1999;84:19-73. http://doi.org/fbg3tx

61. Heaney RP. Protein intake and bone health: the influence of belief systems on the conduct of nutritional science. Am J Clin Nutr. 2001;73:5-6. PubMed PMID: 11124741

62. O’Dea K, Sinclair AJ, Niall M, Traianedes K. Lean meat as part of a cholesterol-lowering diet. Prog Lipid Res. 1986;25:219-20. http://dx.doi.org/10.1016/0163-7827(86)90045-7 63. Dreher ML, Maher CV, Kearney P. The traditional and emerging role of nuts in healthful diets. Nutr Rev. 1996;54:241-5. http://doi.org/dpwhnq

64. Jenkins DJ, Popovich DG, Kendall CW, et al. Effect of a diet high in vegetables, fruit, and nuts on serum lipids. Metabolism. 1997;46:530-7. http://doi.org/d4rk44

65. The Glorious Quran, Chapter 14, Verse 19.

66. The Glorious Quran, Chapter 51, Verse 47.

67. The Glorious Quran, Chapter 24, Verse 45.

68. Conrad LI. Tā' 'ūn and Wabā': conceptions of plague and pestilence in early Islam. Journal of the Economic and Social History of the Orient. 1982;25:268-307. http://doi.org/c9bgv8

69. Bayrakdar M. Al-Jahiz and the rise of biological evolutionism. Islamic Quarterly. 1983; 27:149-55.

70. Masood E. Islam's evolutionary legacy. The Guardian. March 1, 2009. http://bit.ly/KQJjSf 71. Alakbarli F. A 13th-century Darwin? Tusi's views on evolution. Azerbaijan International. 2001;9:48-49. http://bit.ly/KDipeg

72. Ibn Khaldūn. Al-Muqaddimah. Chapter 1. Sixth prefatory discussion. Rosenthal F, translator. http://bit.ly/MEN7UU [Accessed 2012-May-13]

73. Sanders ER. The Hamitic hypothesis: its origins and functions in time perspective. The Journal of African History. 1969;10:521-32. http://dx.doi.org/10.1017/S0021853700009683

74. El Hamel C. 'Race', slavery and Islam in Maghribi Mediterranean thought: the question of the Haratin in Morocco. The Journal of North African Studies. 2002;7:29-52. http://doi.org/cxsfmj

75. Gregory TR. Understanding natural selection: essential concepts and common misconceptions. Evolution: Education and Outreach. 2009;2:15675. http://dx.doi.org/10.1007/s12052-009-0128-1

76. Zampieri F. Origins and history of Darwinian medicine. Humana.Mente. 2009;9:13-38. http://bit.ly/LUFJmb

77. Greaves M. Darwinian medicine: a case for cancer. Nat Rev Cancer. 2007;7:213-21. http://dx.doi.org/10.1038/nrc2071

78. Dossey L. Reinventing medicine: beyond mind-body to a new era of healing. New York: Harper Collins; 1999.

79. Charlton NB. Understanding Gregory Bateson: mind, beauty, and the sacred earth. Albany: State University of New York Press; 2008. 80. Harries-Jones P. A recursive vision: ecological understanding and Gregory Bateson. University of Toronto Press; 1995. 